\author{
Conjugated Linoleic Acid(CLA) 이성체가 돼지 지방전구세포의 \\ 분화에 미치는 영향 \\ 문현석. 정정수 \\ 충북대학교 농과대학 축산학과
}

\title{
Effect of Isomers of Conjugated Linoleic Acid on Porcine Preadipocyte Differentiation
}

\author{
H. S. Moon and C. S. Chung \\ Department of Animal Science, Chungbuk National University
}

\begin{abstract}
The current study was undertaken to determine the effect of various conjugated linoleic acid (CLA) isomers on differentiation of pig preadipocyte during culture. Preadipocyte(stroma-vascular cell) was isolated from the backfat of newborn pigs and cultured to differentiate into mature fat cell. Different doses of CLA isomers were treated to the culture media at different times. Cell differentiation was determined by measuring the glycerol3-phosphate dehydrogenase activity of the cultured preadipocytes. Twenty and fifty $\mu \mathrm{M}$ of trans10-cis12 isomer of CLA inhibited differentiation of pig preadipocyte whereas cis9-cis11 isomer stimulated the differentiation. Both cis9-trans11 and trans9-trans11 isomers showed no effect. Effect of CLA isomer was more evident at the early stage of culture(day 0-8), than the late stage(day 8-14). These results suggest that each CLA isomer has different effect on pig preadipocyte differentiation.
\end{abstract}

(Key words : CLA, Pig, Preadipocyte, Differentiation)

\section{I 서 론}

Ha 등(1987)이 conjugated linoleic acid(CLA)가 항암작용을 나타낸다고 보고한 이래 CLA에 관 한 연구논문이 무수히 발표되었다. 이는 CLA 의 항암작용뿐만 아니라 항동맥경화, 항비만 및 면역증강 작용 등이 여러 실험에 의해 확인 되어 인간의 건강증진에 이용될 가능성이 크기 때문이다(Ip 등, 1994; Lee 등, 1994; Cook 등, 1993; Waylan 등, 2002; Wahle 등, 2004). 한편 축산물 생산의 입장에서는 저지방 육류생산, 면역증강에 의한 가축의 생산성향상 그리고 CLA가 다량 함유된 축산물섭취에 의한 인간의
건강증진 등이 논의의 대상이다. CLA는 linoleic acid(LA)의 이성체로서 이중결합의 위치, 그리고 cis 및 trans form 따라 여러 이성체가 생긴다. 즉 $\mathrm{LA}$ 는 이중결합이 9번과 12번에 탄 소에 있고 논의의 대상이 되는 CLA는 이중결 합이 주로 9 번과 11 번 그리고 10 번과 12 번 탄 소에 있는데, cis와 trans 모두 가능하므로 여러 개의 이성체가 생길 수 있다. 이 중에서 유제 품에 많이 함유되어 있는 것은 cis9-trans11인데 (Ip 등, 1994), 최근에 와서 화학적 합성에 의한 모든 조합의 이성체 생산이 가능하므로 어느 이성체가 위에 설명한 여러 CLA의 작용을 나 타내는지가 중요시 되고 있다.

\footnotetext{
Corresponding author : Dr. Chung Soo Chung, Department of Animal Science, Chungbuk National University, Cheongju, Chungbuk 361-769, Republic of Korea, Phone:82-43-261-2549, E-mail : chungpig@hotmail.com
} 
지방축적의 증가는 세포수의 증가(hyperplasia) 또는 세포크기의 증가(hypertrophy)에 의해서 이 뤄지는데, 지방축적조절을 위해서는 세포수를 조절하는 것이 훨씬 효율적이다. 이와 관련해 서 cell line 또는 primary fat cell을 이용해서 이 들 세포분화에 관한 연구가 많았다. CLA가 지 방세포의 분화에 미치는 연구도 상당히 수행되 었는데, Satory와 Smith(1999)는 CLA가 cell line 지방세포 3T3-L1 cell의 세포분화를 촉진시켰다 고 보고한 반면, Brodie 등(1999)은 CLA가 같은 cell의 분화를 억제했다고 보고했다. 이런 상반 된 결과는 이들이 사용한 CLA가 여러 이성체 의 'mixture'였기 때문에 실험에 사용한 CLA 이성체의 조성이 다른 것이 한 가지 원인으로 사료된다. 한편 Kang 등(2003)은 같은 3T3-L1 cell에서 trans10-cis12 CLA 이성체가 세포의 분 화를 억제했다고 보고했다.

CLA를 돼지에게 투여했을 때 지방축적이 감 소되었기에(Dugan 등, 1997; Ostrowska 등, 1999; Waylan 등, 2002), 이에 대한 작용기전의 구명 일환으로 CLA가 돼지 지방전구세포의 분화에 미치는 영향에 관한 연구가 몇 있었다. Ding 등(2002) 및 McNell과 Mersmann(2003)은 trans10cis12 CLA 이성체가 돼지 지방전구세포의 분화 를 촉진했다고 보고했는데 이는 3T3-L1 cell의 결과와 상반된 것이다. 위와 같이 지방전구세 포의 분화에 미치는 CLA의 작용이 명확하지 않고, 특히 초기의 많은 CLA 관련 연구들이 여러 이성체가 혼합된 CLA를 연구에 사용했기 에 개개 이성체들의 특이 작용을 구명하기 어 려웠다. 또한 개개 CLA 이성체를 사용한 연구 에서도 여러 이성체의 작용을 구명하지 않았 다. 그리고 앞으로 CLA가 돼지의 지방축적억 제제로 사용될 경우 3T3-L1 등 cell line 보다는 돼지에서 분리한 지방전구세포의 분화에 미치 는 $\mathrm{CLA}$ 의 작용의 구명이 더 중요할 것이다.

따라서 본 연구의 목적은 돼지에서 분리 채 취한 지방전구세포를 이용해서 여러 종류의 개 개 CLA 이성체들이 세포의 분화에 미치는 영 향을 구명하는 것이다. 본 연구의 결과는 앞으 로 CLA가 돼지의 지방축적감소 등 생산성 향
상을 위해 사용될 경우 중요한 기초 자료를 제 공해 줄 것이다.

\section{재료 및 방법}

\section{CLA 출처}

본 실험에 사용한 CLA는 Materya(State College, $\mathrm{PA}, \mathrm{USA})$ 에서 구입한 cis9-cis11(9c-11c), cis9trans11(9c-11t), trans9-trans11(9t-11t) 및 trans10cis12(10t-12c) 이성체이었고, CLA 'mixture'는 44\% $10 \mathrm{t}-12 \mathrm{c}$ 이성체를 함유한 것으로 Nu-Chek-Prep (Elysian, MN, USA)에서 구입했다. CLA mixture 를 본 연구에 포함 시킨 이유는, 순수한 개개 CLA 이성체 생산은 비용이 많이 들기에 CLA 가 가축의 생산성 향상을 위해 사용될 경우를 염두에 뒸기 때문이다.

\section{2. 돼지 지방전구세포의 분리 및 배양}

지방전구세포(stroma-vascular cell)는 갓난 돼 지의 등지방 조직에서 분리해서 배양했는데, 요약하면 생후 2 일 이내의 자돈의 등지방을 무 균상태에서 잘라내어 collagenase로 소화시켜 위 에 뜨는 성숙 지방세포는 버리고 바닥에 가라 앉는 지방전구세포를 분리해서 6-well plate에 seeding 했고 seeding 15일 후에 세포의분화정도 를 구명했다. 돼지의 지방전구세포의 분리, 배 양은 Suryawan(1997)의 방법을 따르면서 본 연 구실에서 변경해서 확립했는데 이에 대한 것은 결과 및 고찰에 기술했다. 구체적인 지방전구 세포의 분리 및 배양 방법은 아래와 같다.

생후 $1 \sim 2$ 일령 된 체중 $1.6 \sim 1.7 \mathrm{~kg}$ 의 자돈을 desiccator에서 $\mathrm{CO}_{2}$ gas를 주입하여 질식사 시킨 후 비눗물로 몸 전체를 씻었다. 그리고 요오드 와 알콜로 다시 씻었다. clean bench에서 scapel 을 이용해 돼지 머리 밑에서 견갑골까지 $\mathrm{T}$ 자 모양으로 자른 후 forceps과 blade로 fat tissue를 채취했다. 미리 무게를 측정한 petridish에 지방 조직을 옮겨서 지방조직 $1 \mathrm{~g}$ 당 $3 \mathrm{ml} \mathrm{KRB}$ buffer에 2,000 unit collagenase를 함유시켜 지방조 직을 chopping했다. Chopping한 지방조직을 삼 
각플라스크에 옮긴 후 40 분 동안 shaking water bath에서 incubation했다. 40분 후 $250 \mu \mathrm{M}$ nylon screen으로 filtering해서 collagenase에 의해 소화 되지 않은 조직을 제거한 후 10 분 동안 centrifuge 하고 $\mathrm{KRB}$ buffer로 disperse한 후 다시 10 분 동안 centrifuge 했다. DMEM/F-12로 tube 바닥의 cell들을 disperse 한 후 $75 \mu \mathrm{M}$ nylon screen으로 filter했다. hematocytometer로 cell을 counting 하고 난 뒤 $10 \% \mathrm{FBS}$ 를 함유한 DMEM/F-12을 이용하여 6 well plate에 $1 \times 10^{6}$ cell/well을 seeding했다. Seeding 1 일 후에 적혈 구 등을 제거하기 위해 washing 한 후 분화유 도(day 0)를 위해 insulin(600 ng/ml), trasferrin(1 $\mathrm{ug} / \mathrm{ml}$ ) 및 hydrocortisone(500 ug/ml)(세시약 모 두 Sigma- Aldrich)을 함유한 DMEM/F-12를 세 포배양이 끝날 때 까지 사용했으며 2일마다 배 양액를 교환해 줬다. 대개 cell seeding 한 후 14 일경이 지나면 지방전구세포가 성숙지방세포 로 완전히 분화했다.

\section{CLA 처리}

CLA는 dimethyl sulfoxide(DMSO)로 녹였는데 $50 \mathrm{mM}$ 의 농도로 만들어 $-70{ }^{\circ} \mathrm{C}$ 에서 보관해 뒸 다가 필요할 때 사용했다. 세포배양에 사용한 최종농도는 $50 \mu \mathrm{M}$ 이었는데 6-well plate의 well 당 배양액의 부피가 $2 \mathrm{ml}$ 이므로 well 당 $2 \mu \mathrm{l}$ 의 CLA stock solution을 첨가했고, 대조구는 CLA 를 녹이는 $\mathrm{DMSO}$ 를 $\mathrm{CLA}$ 와 같은 부피를 처리 해서 $\mathrm{DMSO}$ 에 의한 영향을 배제했다. 배양액 교환은 2일마다 했고 이때 마다 새로운 CLA를 처리했다.

\section{4. 세포분화 측정}

돼지 지방전구세포의 분화정도는 지방세포 의 glycerol-3-phosphate dehydrogenase(GPDH) 활 성도를 측정함으로써 구명했다. $\mathrm{GPDH}$ 는 dihydroxyacetone phosphate 를 glycerol-3-phosphate 로 전환시키는 효소인데, glycerol-3-phosphate 는 중 성지방 (triglyceride) 합성에 필요한 물질이기에 지방전구세포가 성숙한 지방세포로 분화했는지
를 구명할 수 있는 효소로 여겨지고 있다. Wise와 Green(1979)의 방법을 따르면서 본 연구 수행에 맞게 용액의 양을 조절했는데 구체적인 측정방법은 다음과 같다. 세포배양이 끝난 후 (대개 day 14) 6-well plate 에 있는 배양액 을 완전히 제거하고 PBS로 남아있는 배양액 을 씻어낸 후 $260 \mu \mathrm{l}$ homogenizing $\operatorname{buffer}(0.25 \mathrm{M}$ Sucrose, $5 \mathrm{mM}$ Tris base, $1 \mathrm{mM}$ EDTA, $1 \mathrm{mM}$ dithiothreitol, $\mathrm{pH}$ 7.4)를 이용하여 6-well plate의 세포들을 eppendorf tube에 수집했다. 그리고 가 루얼음 위에 꽂은 다음 10초 동안 6 watts로 세 포를 sonication 시킨 후 $4{ }^{\circ} \mathrm{C} 12,000 \mathrm{rpm}$ 으로 10 분 동안 원심분리 했다. supernatant 200ul를 취 해서 새로운 eppendorf tube에 옮긴 후 assay buffer(100mM triethanolamine, $2.5 \mathrm{mM}$ EDTA, $0.1 \mathrm{mM}$ B-mercaptoethanol, $0.176 \mathrm{mM} \quad \mathrm{NADH}) \quad 800 \mu \mathrm{l}$ 과 기질인 $0.160 \mu \mathrm{M}$ dihydroxyacetone phosphate lithium solution $100 \mathrm{\mu l}$ 그리고 위의 supernant 150 $\mu \mathrm{l}$ 를 cuvette에 넣고 shaking 한 뒤 $340 \mathrm{~nm}$ 에서 흡광도를 측정하여 $\mathrm{GPDH}$ 값을 산출하였다. 단 백질 측정은 Bradford(1976)의 방법에 따랐는데 모든 세포의 분화정도는 $\mathrm{GPDH}$ 값을 단백질양 으로 나눈 값으로 조사했다.

\section{5. 세포의 중성지방 햠 ㅑㅑㄱ 측정}

6-well plate에서 지방전구세포의 배양액을 제 거하고 난 뒤 PBS로 plate에 남아있는 배양액 를 씻어냈다. 다시 PBS로 plate 바닥의 세포를 수집하고 sonication 한 후 Sigma kit(triglyceride reagents $\mathrm{A}$ 와 $\mathrm{B}$ )을 이용해서 세포의 중성지방 함량을 측정했다.

\section{6. 통계분석}

본 연구의 모든 실험의 data는 student t-test를 이용하여 대조구에 대한 각 처리구를 비교분석 하였는데, 처리구의 값을 대조구(100\%)에 대한 $\%$ 로 표시하였다(\% control). 그 이유는 세포배 양 특히 primary cell 배양성격상 배양시마다 세 포의 분화정도가 다르기 때문에 대조구에 대한 상대적인 값으로 표현하는 것이 합리적이기 때 
문이다. 모든 분석과정은 GLM procedure of the Statistics Analysis System(SAS Institute, Cary, NC. 1998)을 이용하였다.

\section{III 결과 및 고찰}

\section{1. 돼지 지방전구세포의 배양조건 확립}

돼지 지방 전구세포의 적정 배양 조건을 확 립하기 위해 아래와 같이 여러 가지 기초 실험 을 실시하였다. 그러나 세포사멸 등의 현상으로 인해 분화정도를 수치로 표현하지 못하고 육안 으로 관찰한 것을 아래와 같이 기술했다. 분화 유도일(day 0)부터 세포배양이 끝날 때까지(day 14 ) 여러 농도의 $\mathrm{FBS}(0,5$ 및 10\%)와 hydrocortisone $(0,50$ 및 $500 \mathrm{ng} / \mathrm{ml})$ 을 조합하여 실험 을 수행한 결과는 다음과 같다.

$0 \% \mathrm{FBS}+0,50$ 및 $500 \mathrm{ng} / \mathrm{ml}$ hydrocortisone medium에서는 전반적으로 세포들의 사멸현상 이 나타났으며 $10 \% \mathrm{FBS}+0,50$ 및 $500 \mathrm{ng} / \mathrm{ml}$ hydrocortisone medium에서는 분화 전반기에 세 포들의 상태는 좋았으나 분화 후반기로 접어들 면서 $0 \% \mathrm{FBS}$ 와 마찬가지로 세포사멸현상이 나타났다. $5 \% \mathrm{FBS}+0 \mathrm{ng} / \mathrm{ml}$ hydrocortisone medium에서 세포의 상태는 좋았으나 분화가 일어 나지 않았고, $5 \% \mathrm{FBS}+50 \mathrm{ng} / \mathrm{ml}$ cortisol medium에서는 세포의 상태는 좋았지만 분화가 약 하게 일어났다. $5 \% \quad \mathrm{FBS}+500 \mathrm{ng} / \mathrm{ml}$ hydro- cortisone medium에서는 세포의 사멸현상도 사 라졌고 분화가 왕성하게 일어났다. 위의 모든 비교 실험에서 insulin $(600 \mathrm{ng} / \mathrm{ml})$ 과 transferrinn $(1 \mathrm{ug} / \mathrm{ml})$ 의 농도는 동일하게 유지했다. 이러한 결과를 토대로 본 연구의 모든 실험은 $5 \% \mathrm{FBS}$ 에 $500 \mathrm{ng} / \mathrm{ml}$ hydrocortisone이 함유된 DMEM /F12를 사용하였다. Fig. 1은 cell seeding 1일 후 에 적혈구 등 제거를 위해 washing 한 후(day 0) 배양 경과일수에 따른 돼지 지방전구세포의 분 화정도를 보여주고 있다.

\section{CLA 농도가 돼지 지방전구세포의 분화에 미치는 영향}

농도에 따른 $\mathrm{CLA}$ 의 작용을 구명하기 위해 서 여러 CLA이성체를 세포배양 전기간(day 0 14)에 걸쳐 $20 \mu \mathrm{M}$ (Fig. 2), $50 \mu \mathrm{M}$ (Fig. 3) 및 $100 \mu \mathrm{M}$ (date not shown) 처리해서 분화정도를 조사했다. $20 \mu \mathrm{M}$ 농도에서 9c-11t와 9t-11t 이성 체는 아무 작용이 없었으며 $10 \mathrm{t}-12 \mathrm{c}$ 는 세포분화 를 크게 억제했고 $(\mathrm{p}<0.001)$, CLA mix도 억제 했다 $(\mathrm{P}<0.01)$. CLA mix의 억제작용은 여기에 포함되어 있는 $10 \mathrm{t}-12 \mathrm{c}$ 의 작용으로 사료된다. 9c-11c는 분화를 오히려 촉진했다. Fig. 3에서 보는 대로 $50 \mu \mathrm{M}$ 농도에서는 $20 \mu \mathrm{M}$ 농도에 비 해서 이성체들의 작용이 더 명확했다. 유의수 준은 같으나 $10 \mathrm{t}-12 \mathrm{c}$ 와 CLA mix의 분화억제작 용이 더 컸다. 9c-11c의 세포분화 촉진작용도

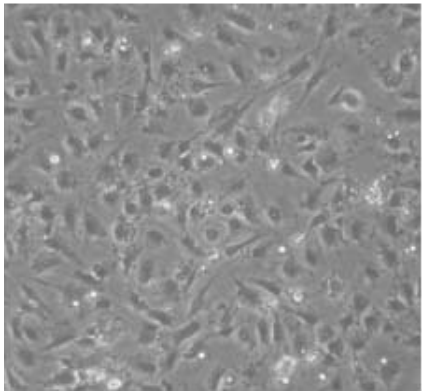

day 0

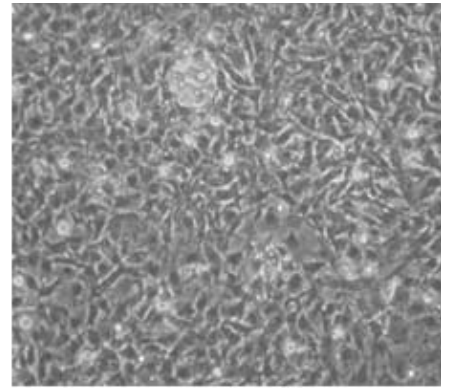

day 1

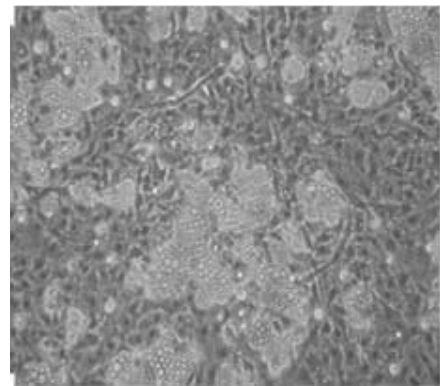

day 12

Fig. 1. Differentiation of pig preadipocytes. The preadipocytes were isolated from the backfat of newborn pig and cultured on DMEM/F-12. The cells were induced to differentiation with insulin, transferrin and hydrocortisone(day 0). On day 12 many mature fat cells appeared. 
$50 \mu \mathrm{M}$ 농도에서 더 크게 나타났다. 9c-11t와 $9 \mathrm{t}-11 \mathrm{t}$ 는 $20 \mu \mathrm{M}$ 에서 처럼 아무런 작용이 없었 다. Kang 등(2003)도 10t-12c 이성체가 3T3-L1 cell의 분화를 억제했다고 보고해서 본 연구결과 와 같은 결과를 보여줬으나 McNeel과 Mersmann (2003)은 10t-12c가 돼지 지방전구세포의 분화 를 촉진했다고 발표해서 본 연구와는 다른 결 과를 보여주었다. 본 연구에서는 성숙세포로의 분화가 완료된 시점에 분화를 측정했고 $\mathrm{McNeel}$ 과 Mersmann(2003)은 배양 초기에 분화정도를 측정한 방법상의 차이점도 있고 $10 \mathrm{t}-12 \mathrm{c}$ 이성체 의 작용이 cell line과 primary cell 간에 다르게 작용할 수도 있으나 돼지 지방전구세포에서도 $10 \mathrm{t}-12 \mathrm{c}$ 이성체가 분화를 억제하는 것으로 여겨 진다. 이에 대한 근거는 본 연구에서 측정한 모든 경우 즉 $10 \mathrm{t}-12 \mathrm{c}$ 이성체를 배양전기간 처 리(Fig. 2와 3), 배양전기 처리(Fig. 4), 배양후기 처리(Fig. 5) 모두에서 10t-12c의 분화 억제작용 이 뚜렷하게 나타났기 때문이다. 한편 본 연구 에서 9c-11c가 지방전구세포의 분화를 촉진한 사실은 흥미롭다. $20 \mu \mathrm{M}$ 과 $50 \mu \mathrm{M}$ 두 농도 모 두에서 억제작용을 나타낸 것은 $9 \mathrm{c}-11 \mathrm{c}$ 의 분화 촉진 작용이 고유한 것임을 나타내는데 Ding 등(2003)도 9c-11c 이성체가 돼지 지방전구세포

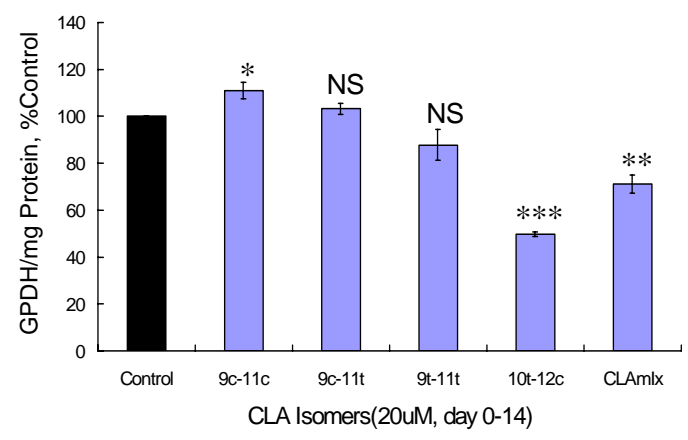

Fig. 2. Effects of CLA isomers on pig preadipocyte differentiation. Cells were treated with $20 \mu \mathrm{M}$ CLA isomers from day 0 to 14 after induction of differentiation. CLAmix contained $44 \%$ $10 \mathrm{t}-12 \mathrm{c}$ isomer. Values are means $\pm \mathrm{SE}, \mathrm{n}=6$; difference from dimethyl sulfoxide(DMSO) treated control cells: NS, not significant; $* p<0.05$; ** $p<$ $0.01 ; * * * \mathrm{p}<0.001$.

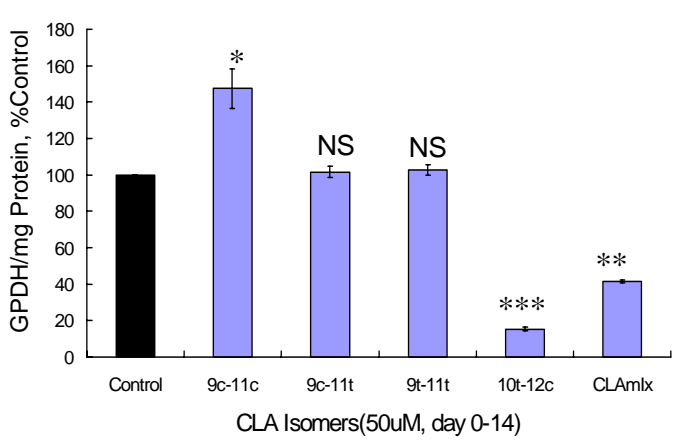

Fig. 3. Effects of CLA isomers on pig preadipocyte differentiation. Cells were treated with $50 \mu \mathrm{M}$ CLA isomers from day 0 to 14 after induction of differentiation. CLAmix contained 44\% $10 \mathrm{t}-12 \mathrm{c}$ isomer. Values are means \pm SE, $n=6$; difference from dimethyl sulfoxide(DMSO) treated control cells: NS, not significant; * $\mathrm{p}<0.05 ; \quad * * \mathrm{p}<$ 0.01 ; *** $\mathrm{p}<0.001$.

의 분화를 촉진한다고 보고했다. 이와 같이 CLA 이성체에 따라 돼지 지방전구세포의 분화에 미치는 작용이 다르다는 사실은 CLA를 지방축 적억제 또는 생산성 향상을 위해 돼지에게 급 여할 때 급여하는 CLA의 조성에 따라 결과들 이 달라질 수 있음을 나타낸다. 이와 관련해서 Thiel-Cooper 등(2001)은 여러 이성체가 혼합된 CLA를 돼지 사료에 $0.12 \%$ 에서 $1 \%$ 까지 함유 시켜 급여했을 때 등지방 두께에 미치는 영향 이 부위에 따라 일정하지 않았음을 보고했다

$100 \mu \mathrm{M}$ 의 CLA 이성체들이 돼지 지방전구세 포의 분화에 미치는 결과는 수치로 나타낼 수 가 없었는데 그 이유는 세포사멸을 가져왔기 때문이다. $20 \mu \mathrm{M}$ 과 $50 \mu \mathrm{M}$ 농도에서 세포분화 를 억제했던 $10 \mathrm{t}-12 \mathrm{c}$ 는 물론이고 분화촉진현상 을 나타냈던 9c-11c 이성체도 배양후기에 접어 들면서 세포사멸현상을 나타냈고, 세포사멸현 상이 가장 두드러졌던 것은 9t-11t 이성체이었 는데 day 4 를 넘기지 못하고 사멸했다.

3. CLA 처리시기가 돼지 지방전구세포의 분 화에 미치는 영향

CLA 처리시기가 세포의 분화에 미치는 영향 
을 구명하기 위해 배양전기(day 0 8)와 배양후 기(day $8 \sim 14$ )에 $50 \mu \mathrm{M}$ CLA 이성체를 처리한 결과가 Fig. 4와 Fig. 5에 나타나 있다. Fig. 4와 5 에서 보는 대로 배양전기가 배양후기보다 CLA 이성체들의 작용이 더 뚜렷했다. $10 \mathrm{t}-12 \mathrm{c}$ 이성체의 분화억제작용이 더 두드러졌고, 9c-11c의 분화촉진 작용은 배양전기에만 나타났다. 배양 전기는 세포의 증식이 일어나는 시기 이기에

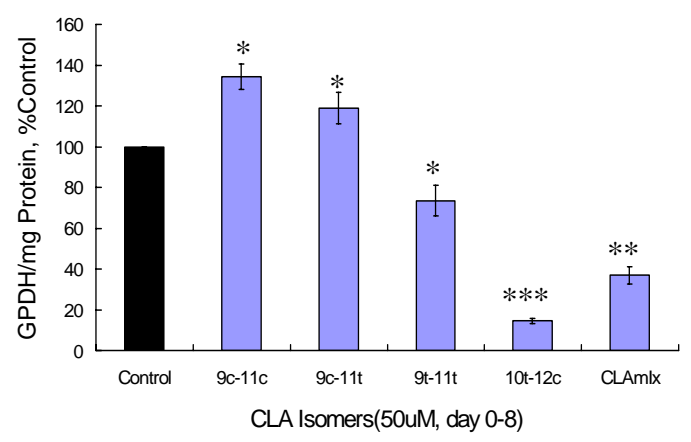

Fig. 4. Effects of CLA isomers on pig preadipocyte differentiation. Cells were treated with $50 \mu \mathrm{M}$ CLA isomers from day 0 to 8 after induction of differentiation. CLAmix contained $44 \%$ $10 \mathrm{t}-12 \mathrm{c}$ isomer. Values are means $\pm S E, n=6$; difference from dimethyl sulfoxide(DMSO) treated control cells: * $\mathrm{p}<0.05 ;$ ** $\mathrm{p}<0.01$; *** $\mathrm{p}<0.001$.

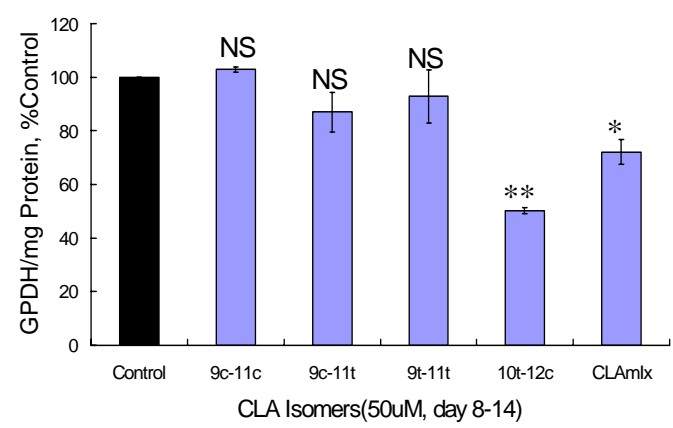

Fig. 5. Effects of CLA isomers on pig preadipocyte differentiation. Cells were treated with $50 \mu \mathrm{M}$ CLA isomers from day 8 to 14 after induction of differentiation. CLAmix contained $44 \%$ 10t-12c isomer. Values are means $\pm S E, n=6$; difference from dimethyl sulfoxide(DMSO) treated control cells: NS, not significant; * $\mathrm{p}<0.05 ;$ ** $\mathrm{p}<0.01$.
이 두 이성체의 작용이 더 두드러지는 것으로 사료된다. 배양전기간에 처리했을 때는 나타나 지 않았던(Fig. 3) 9c-11t와 9t-11t 이성체의 작 용이 배양전기에 처리했을 때 나타난 이유는 (Fig. 4) 설명하기 어려웠다.

CLA 처리시기에 따른 작용을 더 상세히 구명 하기 위해서 세포분화억제작용이 컸던 $50 \mu \mathrm{M}$ $10 \mathrm{t}-12 \mathrm{c}$ 이성체를 14 일 배양기간을 2일씩 7구간으 로 나누어 1 구간(2일) 동안만 처리했을 때의 결 과가 Fig. 6에 나타나 있다. day 2 4 처리가 약 간의 분화억제작용을 나타냈을 뿐 다른 처리시기 에서는 억제작용을 나타내지 않았는데 CLA 처리 기간이 짧았던 것이 그 이유로 사료된다. 즉, 전 체 배양기간이 길었기 때문에(14일), 예로 배양초 기에 2일 동안 $10 \mathrm{t}-12 \mathrm{c}$ 를 처리한 경우 그 뒤의 무 처리 배양기간 동안에 분화억제작용이 무력화되 었을 것으로 사료된다.

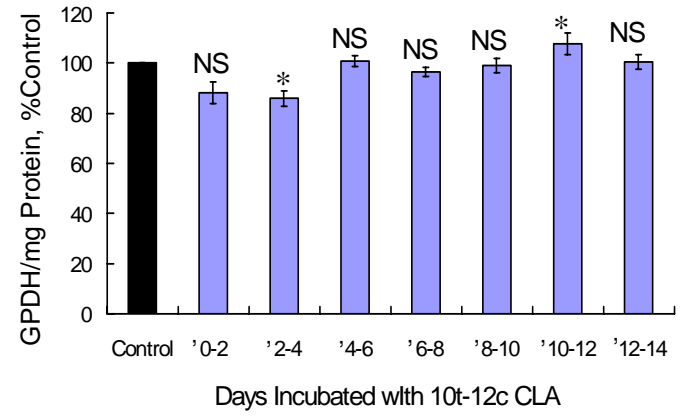

Fig. 6. Effects of CLA treatment time on pig preadipocyte differentiation. Cells were cultured in the presence of $50 \mu \mathrm{M}$ $10 \mathrm{t}-12 \mathrm{c}$ isomer only during the indicated period of the 14-day culture period. Values are means $\pm S E, n=6$; difference from dimethyl sulfoxide (DMSO) treated control cells: NS, not significant; $* p<0.05$.

4. CLA 처리가 돼지 지방전구세포의 중성지 방합성에 미치는 영향

본 연구에서 지방전구세포에서 성숙세포로의 분화정도를 $\mathrm{GPDH}$ 의 활성도로 측정해서 구명 했는데, 이 효소의 측정이 성숙세포로의 분화 정도를 옳게 측정했는지를 구명하기 위해서 CLA 처리가 지방세포의 중성지방(triglyceride) 
합성에 미치는 영향이 Fig. 7에 나타나 있다. $10 \mathrm{t}-12 \mathrm{c}$ 이성체는 중성지방합성을 현저히 억제 했고, 9c-11c 이성체는 증가시켰다. 이 결과는 Fig. 3에 나타난 CLA가 지방세포분화에 미치는 작용을 잘 반영하고 있다.

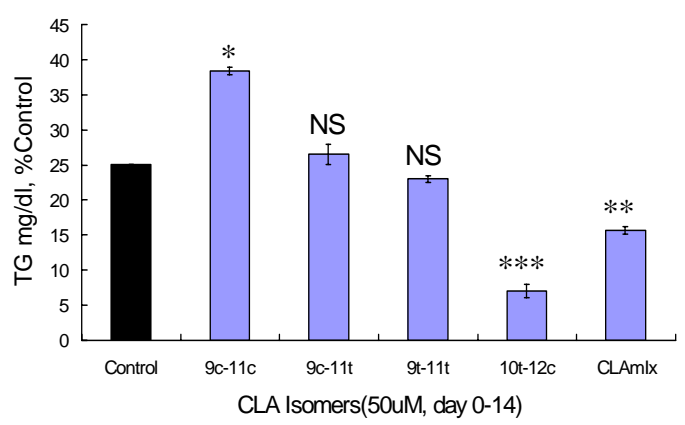

Fig. 7. Effects of CLA on triglyceride synthesis of pig preadipocyte. Cells were cultured in the presence of $50 \mu \mathrm{M}$ CLA isomers during the 14-day culture period after induction of differentiation. Triglyceride synthesis was measured on day 14. Values are means $\pm S E, n=6$; difference from DMSO(dimethyl sulfoxide) treated control cells: NS, not significant; * $p<0.05 ; * * p<0.01$; $* * * \mathrm{p}<0.001$.

본 연구의 결과를 요약하면 10t-12c CLA 이 성체는 신생자돈에서 분리, 채취한 지방전구세 포의 분화를 크게 억제했고, 9c-11c 이성체는 촉진했으며 9c-11c와 9t-11t 이성체는 그 작용이 뚜렷하지 않았다. CLA의 위와 같은 작용은 세 포배양후기보다는 배양전기에 더 뚜렷하게 나 타났다. 위의 결과는 CLA를 가축의 지방축적 억제제로 사용할 경우 CLA이성체 각각의 특이 한 작용을 고려해야 함을 나타낸다.

$$
\text { IV 요 약 }
$$

본 연구는 여러 conjugated linoleic acid(CLA) 이성체가 돼지 지방전구세포의 분화에 미치는 영향을 구명하기 위해 수행하였다. 돼지 지방 전구세포는 갓난 돼지의 등 지방에서 분리해서 성숙지방세포로 분화될 때 까지 배양했다. 여
러 CLA 이성체를 배양중의 세포에 처리했다. 세포분화는 세포배양이 끝난 후 세포의 glycerol-3-phosphate의 활성도를 측정함으로써 구명했 다. $20 \mu \mathrm{M}$ 과 $50 \mu \mathrm{M}$ 의 trans 10 -cis 12 CLA 이성 체는 돼지 지방전구세포의 분화를 억제했고, 한편 cis9-cis11 이성체는 세포분화를 촉진했다. cis9-trans11과 trans9-trans11 이성체는 세포분화 에 아무런 영향을 미치지 않았다. CLA의 세포 분화에 미치는 작용은 배양후기(day 8 14) 보 다 배양전기(day $0 \sim 8$ )에 더 두드러지게 나타냈 다. 위의 결과는 여러 CLA 이성체는 돼지 지 방전구세포 분화에 각각 다른 작용을 가짐을 나타낸다.

$$
\mathrm{V} \text { 사 사 }
$$

본 연구는 농림부의 농림기술개발연구사업의 지원(2000 2002)으로 수행된 연구결과의 일부 이며, 연구비 지원에 감사드립니다.

\section{$\mathrm{VI}$ 인 용 문 헌}

1. Brodie, A. E., Manning, V. A., Ferguson, K. R., Jewell, D. E. and Hu, C. Y. 1999. Conjugated linoleic acid inhibits differentiation of pre- and postconfluent 3T3-L1 preadipocytes but inhibits cell proliferation only in preconfluent cell. J. Nutr. 129: 602-606.

2. Bradford, M. M. 1976. A rapid and sensitive method for the quantiation of microgram quantities of protein utilizing the principle of protein dye binding. Anal. Biochem. 72:248-254.

3. Cook, M. R., Miller, C. C., Park, Y. and Pariza, M. W. 1993. Immune modulation by altered nutrient metabolism-nutritional control of immune-induced growth depression. Poult. Sci. 72:1301-1305.

4. Ding, S-T., McNell, R. L. and Mersmann, H. J. 2002. Conjugated linoleic acid increases the differentiation of porcine adipocytes in vitro. Nutrition Research 20:1569-1580.

5. Ding, S. T., Wang, J. C. and Mersmann, H. J. 2003. Effect of unsaturated fatty acid on porcine adipocyte differentiation. Nutrition Research 23:1059- 1069.

6. Dugan, M. E. R., Aalhus, K. L., Schaefer, A. L. and Kramer, J. K. G. 1997. The effects of linoleic acid on fat to lean repartitioning and feed con- 
version in pigs. Can. J. Anim. Sci. 77:723-725.

7. Ha, Y. L., Grimm, N. K. and Pariza, M. W. 1987. Anticarcinogens from fried ground beef: heat-altered derivatives of linoleic acid. Carcinogenesis. 8:18811887.

8. Ip, C., Scimerca, J. A. and Thompson, H. J. 1994. Conjugted linoeic acid, a powerful anticarcinogen from animal fat sources. Cancer 74:1050-1054.

9. Kang, K., Liu, W., Albright, K. J., Park, Y. and Pariza, M. W. 2003. trans-10, cis-12 CLA inhibits differentiation of 3T3-L1 adipocytes and decreases PPAR $\gamma$ expression. BBRC 303:795-799.

10. Lee, K. N., Kritchevsky, D. and Pariza, M. W. 1994. Conjugated linoleic acid and atherosclerosis in rabbits. Atherosclerosis 108:19-25.

11. McNell, R. L. and Mersmann, H. J. 2003. Effects of isomers of conjugated linoleic acid on porcine adipocyte growth and differentiation. J. Nutr. Biochem. 14:266-274.

12. Ostrowska, E., Mualitharan, M., Cross, R. F., Bauman, D. E. and Dunshea, F. R. 1999. Dietary conjugated linoleic acids increase lean tissue and decrease fat deposition in growing pigs. J. Nutr. 129:2037-2042.

13. SAS. 1998. SAS User's Guide: Statistics, SAS Inst, Inc., Cary, N.C.

14. Satory, D. and Smith, S. B. 1999. Conjugated linoleic acid inhibits proliferation but stimulates lipid filling of murine 3T3-L1 preadipocytes. J.Nutr. 129:92-97.

15. Suryawan, A., Swanson, L. V. and Hu, C. Y. 1997. Insulin and hydrocortisone, but not triiodothyronine, are required for the differentiation of pig preadipocytes in primary culture. J. Anim. Sci. 75: 105-111.

16. Thiel-Cooper, R. L., Parrish, F. C., Sparks, J. C., Wiegand, B. R. and Ewan, R. C. 2001. Conjugated linoleic acid changes swine performance and carcass composition. J. Anim. Sci. 79:1821-1828.

17. Wahle, K. W. J., Heys, S. D. and Rotondo, D. 2004. Conjugated linoleic acids: are they beneficial or detrimental to health? Progress in Lipd Reaearch. 43:553-587.

18. Waylan, A. T., O’Quinn, P. R., Unruh, J. A., Nelssen, J. L., Goodband, R. D., Woodworth, J. C., Tokach, M. D. and Koo, S. I. 2002. Effects of modified tall oil and vitamin $\mathrm{E}$ on growth performance, carcass characteristics, and meat quality of growing-finishing pigs. J. Anim. Sci. 80:1575-1585.

19. Wise, L. S. and Green, H. 1979. Participation of one isozyme of cytosolic glycerophosphate in adipose conversion of 3 T3 cells J. Biol. Chem. 254: 273-275.

(접수일자 : 2004. 11. 2. / 채택일자 : 2004. 12. 20.) 